\title{
Neurocognition of aging in working environments
}

\author{
Patrick D. Gajewski • Michael Falkenstein
}

Accepted: 8 July 2011 / Published online: 16 August 2011

(C) Institut für Arbeitsmarkt- und Berufsforschung 2011

\begin{abstract}
Aging is accompanied by changes in sensory, motor and cognitive functions. Particularly, a high status of socalled fluid cognitive functions is crucial for the employability at an older age. This status, which can be assessed by psychometric and neuroimaging methods, depends on a number of factors like physical constitution, nutrition, education and work demands. This paper systematically analyses factors affecting cognitive functions in aging and reviews current neuroscientific findings regarding training induced neuronal plasticity and compensation of cognitive declines in aging. In the second part the relationship between cognitive functions and the type of work will be discussed and the project PFIFF presented as an example for transfer of neuroscientific basic research to an applied context that aimed at ameliorating and evaluating age- and job-related cognitive deficits. The results of the first project period showed that cognitive decline, as revealed in behavior and brain wave data, may be accelerated by long-lasting unchallenging work and, hence, may occur already in middle age. In the second part of PFIFF a 3-month program consisting of a supervised cognitive training was implemented in a group of 120 assembly-line employees. Before and after the training
\end{abstract}

P.D. Gajewski · M. Falkenstein

Leibniz Research Centre for Working Environment and Human

Factors, Technical University of Dortmund (IfADo),

WHO Collaborating Research Center, Dortmund, Germany

P.D. Gajewski · M. Falkenstein

Leibniz-Institut für Arbeitsforschung an der TU-Dortmund

(IfADo), Dortmund, Germany

P.D. Gajewski $(\varangle)$

Leibniz Research Center for Working Environment and Human

Factors, Ardeystr. 67, 44139 Dortmund, Germany

e-mail: gajewski@ifado.de

url: http://www.ifado.de a comprehensive battery of psychometric and EEG-based tests was administered. The results provide evidence that training in older employees with repetitive work improves impaired cognitive abilities and brain processes found in the first part of the project. These beneficial effects are apparently mediated by preserved brain plasticity in middle-aged and older individuals. This training approach appears to be suitable in order to improve mental fitness of elderly employees. The PFIFF project can be seen as a part of a comprehensive program for promoting mental fitness in older employees.

Keywords Aging · Work · Cognition · Training · Cognitive neuroscience $\cdot$ Neuronal plasticity $\cdot$ ERP

\section{Neurokognition des Alterns im Arbeitskontext}

Zusammenfassung Alter geht mit Veränderungen sensorischer, motorischer, und kognitiver Funktionen einher. Insbesondere ein guter Status von sogenannten fluiden kognitiven Funktionen ist kritisch für die Beschäftigungsfähigkeit von älteren Arbeitnehmern.

Der Status, der mit Hilfe von psychometrischen Tests und neurowissenschaftlichen bildgebenden Verfahren untersucht werden kann, hängt von einer Reihe von Faktoren ab, wie Ernährung, Ausbildung und die Art der Arbeit. Der Artikel analysiert systematisch Faktoren, die kognitive Funktionen im Alter beeinflussen und liefert eine Übersicht über die aktuellen neurowissenschaftlichen Erkenntnisse im Bereich der Neuroplastizität und Kompensation im Alter. Im zweiten Teil des Artikels wird der Zusammenhang zwischen kognitiven Funktionen und dem Arbeitstyp beleuchtet und das Projekt PFIFF präsentiert, das ein Beispiel für eine erfolgreiche Übertragung der neurowissen- 
schaftlichen Grundlagenforschung auf den angewandten, arbeitsbezogenen Kontext darstellt. Ziel des Projekts „PFIFF“ war es, alters- und arbeitsbedingte kognitive Einbußen älterer Beschäftigter mit verhaltens- und neurowissenschaftlichen Methoden zu analysieren, und Maßnahmen zur Reduktion möglicher Defizite zu erarbeiten. In der ersten Phase konnte gezeigt werden, dass kognitive Beeinträchtigungen und Veränderungen von Hirnfunktionen durch langjährige, monotone Arbeit beschleunigt werden und bereits im mittleren Erwachsenenalter auftreten können. In der zweiten Phase wurde bei 120 Teilnehmern mit monotoner Montagearbeit ein trainergeführtes kognitives Training über einen Zeitraum von drei Monaten durchgeführt. Vor und nach dem Training wurde eine umfangreiche Batterie psychometrischer und EEG-basierter Tests durchgeführt. Die Ergebnisse zeigen, dass das Programm beeinträchtigte kognitive Funktionen und Hirnprozesse verbesserte, die im ersten Teil des Projektes gefunden wurden. Offensichtlich wird der Effekt durch noch im mittleren und höheren Alter bestehende Hirnplastizität vermittelt. Mit diesem Trainingsansatz lässt sich also die mentale Fitness älterer Beschäftigter verbessern. Insgesamt kann das Projekt PFIFF als Teil eines umfassenden Ansatzes zum Erhalt und zur Förderung der mentalen Gesundheit älterer Arbeitnehmer verstanden werden.

Schlüsselwörter Alter · Arbeit · Kognition · Training · kognitive Neurowissenschaft · neuronale Plastizität · EKP

\section{Demographic change and work}

Apart from a lower birth rate that shifts the ratio of young vs. old people, the demographic change includes also an increase of the lifespan. Consequently, the average age of workforce increases continuously (Ilmarinen 2006). However, this progress is problematic for a number of reasons. There is a shift in the general working demands: whereas hard physical work successively decreases, psychological demands of work clearly increase. Monotonous and nonself-paced work is often accompanied by higher competition, time pressure and increasing worry about job loss (Flake 2001; Lenhardt 2005). The follow-up costs emerging from such psychosocial factors are meanwhile higher than those arising from physical work-related diseases (Sockoll 2009). Moreover, there are considerable changes in the psychological constitution with increasing age (Baltes and Graf 1996). Thus, there is an open question about the impact of burdensome working environments on mental health and fitness in middle-aged and elderly employees, and which interventions are suitable to slow down psychological aging and to enhance the employability of the elderly workers.

\section{The course of psychological functions across the lifespan}

All human behavior and each occupational activity is a product of several sensory, cognitive, motor and emotionalmotivational functions. These functions are implemented by neuronal and hormonal mechanisms within the central nervous system (CNS). The development of these functions proceeds very differently: whereas the sensory and motor functions maturate during childhood, cognitive and hormonal functions maturate at puberty, while the development of some of the executive or cognitive control functions may well continue throughout adolescence (see Blakemore and Choudhury 2006, for a review).

The age-related alteration of these functions also proceeds in a very different manner: sensory functions like seeing and hearing decline with age already early, which hampers perception and verbal communication (Pichora-Fuller et al. 1995; Baltes and Lindenberger 1997). Changes of cognitive functions and in particular the starting point and speed of their age-related change strongly depend on the type of the function (Fig. 1). In order to categorize different cognitive dimensions, it is helpful to go back to the model of fluid and crystallized intelligence proposed by Cattell (1963) adapted later to aging research by Baltes (1987). Crystallized intelligence is the ability to use skills, knowledge, and experience. It should not be equated with memory, but it depends on accessing information from long-term memory. Crystallized abilities rely on accumulation of knowledge (Baltes 1987; Staudinger and Heidemeier 2009) and are relatively robust and remain unchanged or even improve in higher age. Only after considerable deterioration of long-term memory crystallized abilities also get affected. Social skills, e.g. reasoning about social conflicts, improve with increasing age (Grossmann et al. 2010). In contrast, fluid intelligence represents the capacity to think logically and solve problems in novel situations, largely independently from acquired knowledge. The primary role of fluid intelligence is the planning and implementing of goal-directed behavior, and the flexible coping with new and unexpected situations. Fluid intelligence subsumes a number of cognitive abilities like short-term and working memory, spatiotemporal orienting, selective and divided attention, speed of processing, search for information in the environment, inhibition of pre-potent responses or irrelevant information, error perception, multitasking or task switching. Nearly all of these functions show an age-related decline (West 1996; Baltes and Lindenberger 1997; Baltes and Lindenberger 1988; Madden et al. 1999; Craik and Salthouse 2000; Kray and Lindenberger 2000; Raz 2000; Falkenstein et al. 2001; Verhaeghen and Cerella 2002; Gazzaley et al. 2005; Kramer and Madden 2008; Salthouse 2009; Hahn et al. 2010). However, the decay of 


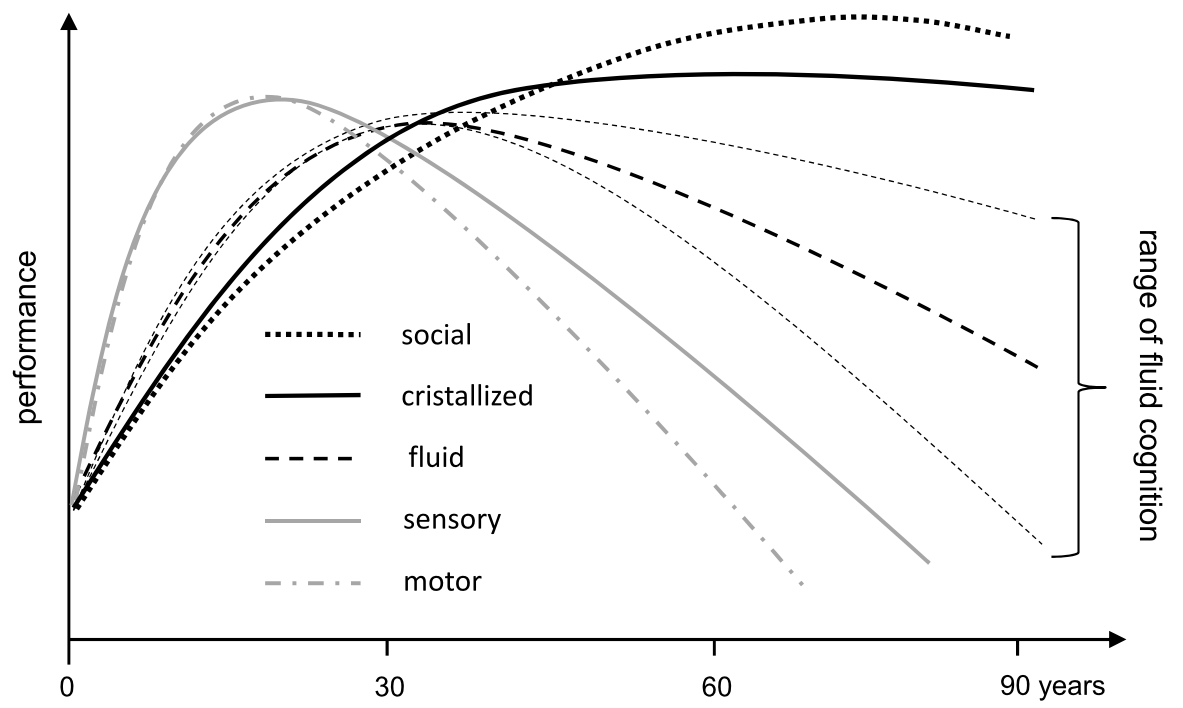

Fig. 1 The course of crystallized and fluid cognitive functions across the lifespan adapted from Baltes (1987) basing on the theory of intelligence proposed by Cattell (1963). The black solid curve indicates improvement of crystallized abilities like language and knowledge. The black dotted curve reflects age-related decline of fluid cognitive functions like working memory, attention, speed of processing, etc. The slim dotted limiting curves indicate the large interindividual variability

fluid functions is extremely different among individuals, and some individuals preserve a high level of fluid functions until very old age (Hultsch and MacDonald 2004). The dotted limiting lines in Fig. 1 indicate the large interindividual variability of the time course of fluid intelligence.

Taking together, aging is characterized by stable or even improved crystallized and social abilities, an early decline of sensory functioning and a somewhat later decline of fluid cognitive functions, the latter showing a huge interindividual variability. Most of the fluid functions are highly relevant for daily life and occupation, particularly in complex and highly demanding environmental situations which require fast information analysis, decisions and responses, such as driving in complex situations (Falkenstein and Poschadel 2008). Impairments of sensory functions can be eliminated or reduced by using technical adjuvants. However, the use of technical tools to eliminate or compensate cognitive deficits is to date not possible. On the other hand, the large variability in the fluid functions between individuals points to factors that could possibly be manipulated to improve these functions. Thus, extraction of factors that affect cognitive processing is one of the main areas of cognitive aging research. Moreover, investigating protective factors against decline, methods for compensation and interventions to improve fluid cognition in elderly workers plays a crucial role for the work quality and employability in older age. of the fluid functions with increasing age. The fat, punctured black curve reflects continuous improvement of social competencies with age, adapted from Grossmann et al. (2010). The gray solid line indicates the course of sensory functions (vision and hearing) adapted from Baltes and Lindenberger (1997). The gray dotted curve indicates a hypothetical course of motor functions like motor speed and motor skills

\section{Neuronal plasticity and compensation in aging}

As outlined above, there is little doubt that there are substantial and reliable age-related declines on measures such as speed of processing, attentional processes, executive functions, episodic memory and fluid intelligence in general (West 1996; Raz 2000; Salthouse 2009). Despite the pioneering idea that the brain and its functions are not fixed throughout adulthood which was proposed already in 1890 by William James (1890) in The Principles of Psychology, this issue was largely neglected and it has been assumed for a long time that cognitive declines are inevitable and the aging brain is not capable anymore to change the neuronal structures or functions. This view was initially supported by neuroanatomical and functional deficits: the volume of key brain structures and the integrity of white matter connections decrease with age which was directly related to cognitive deficits (e.g. Flood and Coleman 1988; Gur et al. 1991). However, later reports showed that the cognitive decline in elderly is not unequivocally associated with singular changes like shrinkage of the brain volume (Van Petten 2004; Van Petten et al. 2004), white matter atrophy (Bartzokis 2004), neuron loss (Morrison and Hof 1997) or synapse loss (Masliah et al. 2006), as originally assumed. Multiple sources or their interaction are better suited to explain the cognitive decline in aging. This helps to understand which neuronal components are involved in a particular cognitive function and how these components can be affected to modify the cognitive system. In recent years there 
is an increasing interest in factors that can ameliorate the cognitive and brain aging (see Greenwood and Parasuraman 2010 for review). The starting point of these considerations was the observation of the huge interindividual differences in the cognitive performance in elderly (Hultsch and MacDonald 2004). These can either be due to genetic differences (e.g. APOE: De Blasi et al. 2009; BDNF: Gajewski et al. 2011; FGF20: Lemaitre et al. 2010; or TNF-alpha: Baune et al. 2008) or rather by different amounts of cognitive reserve (Stern 2009), that is protection against decline offered by a history of social and cognitive engagement. The cognitive variability in older age is apparently a result of many different experiences and influences across the life history (Bielak et al. 2007; Stern 2009). For example, a long education during childhood has a preventive effect on cognitive decline (Colsher and Wallace 1991) and significantly influences brain activation also in old age (Springer et al. 2005). Interindividual differences may also be due to differences in the ability to adapt and to compensate deficits by increased activation of additionally recruited neuronal networks (Grady 1996; Grady et al. 2005; Spreng et al. 2010). A number of studies (Cabeza 2002; Cabeza et al. 2002; Davis et al. 2008; Reuter-Lorenz et al. 2000; Park and Reuter-Lorenz 2009) showed a bilateral activation of prefrontal cortex in elderly, whereas young participants' activation pattern was unilateral. Most importantly, Cabeza et al. (2002) showed that bilateral prefrontal activation was seen only for high-performing old subjects, suggesting a recruitment of additional prefrontal brain areas to compensate cognitive decline and to maintain the same level of performance as in young people. According to the evolutionary principle of behavioral and neuronal adaptation, recruitment of additional brain areas implicates neuronal plasticity that is induced whenever the neural system is confronted with difficult or new situations and when previously established behavioral repertoire is not sufficient to manage the environmental requirements. This supports the notion that novel experiences stimulate processes of neural plasticity mediated by gene expression that in turn enhances cognitive processing (Rampon et al. 2000) even in older age (Swaab and Bao 2011). The association between experience and neural plasticity has been repeatedly reported both in animal and human studies (Arendash et al. 2004; Bhardwaj et al. 2006; Curtis et al. 2007; Eriksson et al. 1998; Frick and Fernandez 2003; Kempermann et al. 1997; Milgram et al. 2006). New experiences or managing of complex situations are a form of learning which are accompanied by synaptic plasticity (Whitlock et al. 2006) and neurogenesis (Pereira et al. 2007). It has been also shown that synaptic loss in elderly is reversible by a number of activities (Greenwood 2007) which has important implications for the current issue. This highlights the role of new experience and learning to enhance the cognitive reserve (Stern 2009) and to preserve intact fluid cognitive abilities in old age.
4 General factors affecting cognitive functions in aging

As outlined in the previous chapter, recent research shows that older brains are capable to neuronal and cognitive plasticity. Neuronal plasticity can be stimulated by environmental requirements which enhance fluid cognition. This suggests an interaction between environment and the brain as a consequence of adaptation. The most consistent improvements of fluid cognition in older age were found in studies investigating effects of physical aerobe exercise across several months (Colcombe and Kramer 2003; Colcombe et al. 2004; Erickson et al. 2011; Klusmann et al. 2010; Kramer et al. 1999, 2006; Kramer and Erickson 2007; VoelckerRehage et al. 2010, 2011; see also Hillman et al. 2008 for review). Colcombe et al. (2004) found particular improvements of so-called executive functions and working memory, i.e. fluid functions, after 6 months 3 times per week and 45 minutes per session. Acute effects of exercise on the working memory were also shown already 30 minutes after the exercise (Pontifex et al. 2009). There are a number of mechanisms which are involved in the beneficial effects of exercise on cognition. These are neurogenesis and volume increase of the hippocampus, a brain area strongly associated with learning and memory (Erickson et al. 2011; van Praag et al. 1999, 2005), enhanced synaptic plasticity (Pereira et al. 2007) induced by several neurotrophins like BDNF (brain-derived neurotrophic factor, Erickson et al. 2008, 2010) or increase of cerebral blood flow (Burdette et al. 2010). It is likely that these factors interact with each other or are preconditions of some of them (Lessmann et al. 2003).

The second factor which affects brain activity and indirectly cognitive processing is dietary restriction and nutrition. It has been shown that dietary restriction extends the lifespan, reduces age-related diseases (Walford et al. 1999) and enhances memory function (Witte et al. 2009). Regarding nutrition, some reports indicated a beneficial effect of resveratrol, a natural polyphenol abundant in grapes and red wine on the health (see Baur and Sinclair 2006 for review). On the contrary, high-fat diet reduces neuronal plasticity in hippocampus and accelerates cognitive deficits (Greenwood and Winocur 2005; Wu et al. 2008). Furthermore, a number of vegetables, fruits and food containing unsaturated fatty acid like fish have a positive effect on fluid cognition (Falkenstein 2008; Kang et al. 2005).

Finally, non-physical training also increases brain plasticity by cognitively challenging extracurricular activities like complex parlor games, dancing or playing an instrument (Elbert et al. 1995; Verghese et al. 2009). Another possibility is formal cognitive training that focuses on one domain only, for example memory (Jaeggi et al. 2008), attention (Green and Bavelier 2003), visual search (Becic et 
al. 2008), dual task (Bherer et al. 2005) or task switching (Karbach and Kray 2009). In most studies the training effects were restricted to trained function and did not transfer upon other functions (e.g. Willis and Schaie 1986, Willis et al. 2006) while some reports showed also transfer effects upon non-trained activities (e.g. Ball et al. 2007; Cassavaugh and Kramer 2009; Caserta et al. 2007; Edwards et al. 2009; Gopher et al. 1994; Karbach and Kray 2009). However, this can also be due to an implicit involvement of non-explicitly trained functions in the trained function (see Kramer and Morrow 2008). As a consequence from the training literature it appears beneficial to conduct a training that involves several fluid functions relevant for work and daily life. In fact, it has been found that training of a complex video game improved different cognitive functions (Basak et al. 2008). In a recent study conducted by our group (Gajewski et al. 2010a), 150 participants were randomly assigned to one of four groups: physical, cognitive and relaxation training, or a control group. Participants were trained 4 months, two times per week and 90 minutes per session. The results clearly show improvements in the cognitive training group that received a multilayered paper and pencil and PC-based training. However, these improvements were restricted primarily to the accuracy or enhanced probability to memorize or detect target stimuli. These improvements were associated with changes of event-related brain activity (see below) after training.

\section{Cognitive functions and the type of work}

Long-term cognitive engagement has a beneficial effect on cognition by protecting age-related decline or enhancing compensatory mechanisms (Hultsch et al. 1999; Schooler and Mulatu 2001; Schooler et al. 1999; Singh-Manoux et al. 2003; Wilson et al. 1999). Challenging work represents such an important cognitive stimulation (Alvarado et al. 2002; Bosma et al. 2002; Marquié et al. 2010; Wild-Wall et al. 2009) which considerably reduces the risk of dementia in older age (Andel et al. 2005; Lee et al. 2010; Stern et al. 1994; Swaab and Bao 2011).

In a longitudinal study Schooler et al. (1999) investigated effects of complex and cognitive demanding work on cognitive performance across 20 years. The authors showed that demanding jobs improved cognitive performance, particularly in older employees. Potter et al. (2008) observed a similar beneficial effect of demanding work in a sample of about 1000 older workers across a time range of 7 years, whereas tedious physical job demands tended to impair cognition in the workers regardless of age, intelligence and education.

Furthermore, in a recent longitudinal study Marquié et al. (2010) analyzed performance in cognitive tasks as a function of cognitive work demands in about 3000 workers. The authors could show that the more cognitively stimulating the work the higher the scores in tests of episodic memory, attention and speed of processing, and the more favorable the change of these functions over a 10-year followup. High cognitive stimulation at work made the employees even smarter over the ten years than worse.

These findings suggest that intellectually stimulating work may prevent decline or even improve cognitive functions with increasing age. A simple and effective method to enrich the working environment and prevent monotony is rotation of work places and job assignment. For example, Frieling and Weichel (2008) showed that rotation of job tasks enhanced the employability and problem solving in older individuals.

Shift work and night work have several consequences on the human's health due to atypical biological times. Workers, exposed to shift and night work, have a higher risk for unfavorable alterations of hormones, hypertension, coronary heart disease and cancer (see Costa 1996 for an overview). A phase shift as experienced in night and rotating shift work involves de-synchronization at the molecular level in the circadian oscillators in the central nervous system and in most peripheral tissues of the body (Haus and Smolensky 2006). The disturbance of the circadian rhythms affects also fluid cognitive functions. Findings obtained by Ansiau et al. (2008) showed that physical activity and work between 10 pm and 6 am had a detrimental effect on cognition at the following day. Rouch et al. (2005) investigated the influence of shift work on the verbal memory in about 3000 workers. The memory performance was lower in the shift workers than the non-shift workers. Moreover, there was a relationship between the performance in the memory test and the duration of shift work exposition, suggesting lower performance in individuals with longest shift work biographies. Most importantly, the detrimental effect of shift work was reversible: after the shift work was eliminated, the memory performance recovered four years later. This implies that shift work alters cognitive functions, at least if shift work is administered for a long time. As unchallenging and monotonous job demands and shift work are often associated, the risk of cognitive decline is considerably enhanced in such combinations.

\section{Measurement of cognitive functions in humans}

The status of fluid cognitive functions can be reliably assessed by measures of response times and error rates in standardized psychometric tests. However, these performance parameters represent the outcome of a sequence of sensory, cognitive and motor processes which do not allow identifying the source of age-related or pathological change in 


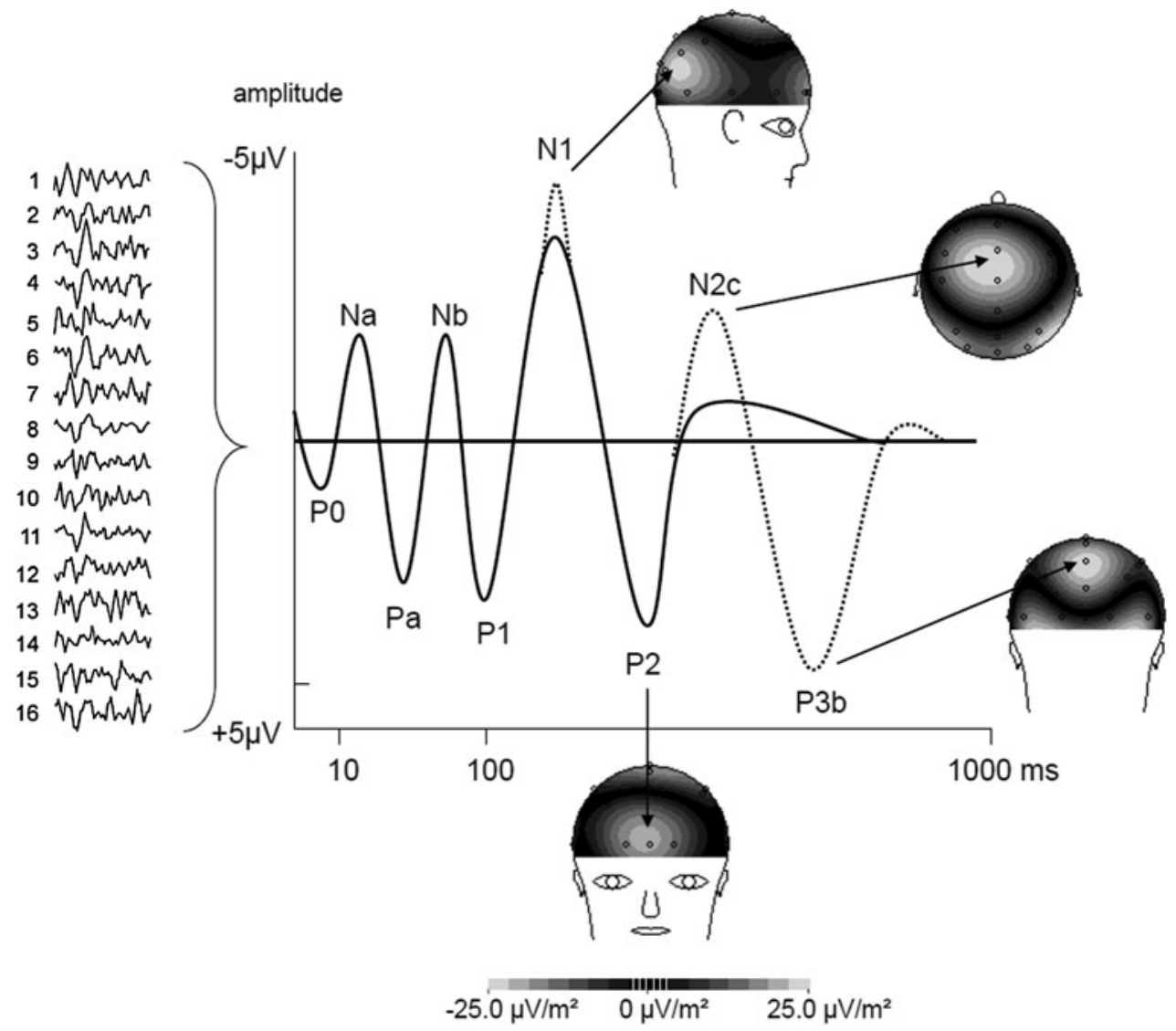

Fig. 2 A schematic illustration of event-related potentials (ERP). The EEG epochs obtained in single trials 1-16 were averaged. After averaging the random activity was reduced and event related activity increased (e.g. to the stimulus). As a result, a sequence of peaks occurred. The early peaks are related to physical features of the stimulus, whereas the later peaks are associated with particular cognitive processes like selective attention (P1 and $\mathrm{N} 1)$, stimulus evaluation (P2), response selection and conflict processing (N2c) and allocation of cognitive resources and working memory ( $\mathrm{P} 3 \mathrm{~b})$. The dotted waves indicate the variability of the amplitude depending on the intensity of the involved cognitive process. The distribution of the electric potentials can be visualized in form of topographical maps that illustrate the highest current densities on the scalp at a particular point in time. The time axis is logarithmic scaled the central nervous system. Moreover, overt performance may be influenced by compensatory processes which remain undetected with behavioral measures. The application of brain imaging methods like functional magnetic resonance imaging (fMRI) or event-related potentials (ERP) provide additional information about the topography, intensity and timing of cognitive processes. FMRI measures the hemodynamic response (change in blood flow) related to neural activity in the brain or spinal cord and has an excellent spatial but relatively low temporal resolution (see Cabeza and Kingstone 2006 for introduction). ERPs were extracted from the electroencephalogram (EEG), a procedure that measures electrical activity of the brain through the skull and scalp. As the EEG reflects a number of simultaneously ongoing brain processes, the brain response to a single stimulus or event of interest is not usually visible in the EEG recording of a single trial. To see the brain response to the stimulus many trials were averaged, causing random brain activity to be reduced and the relevant
ERP to be highlighted (Fig. 2). After the averaging, a sequence of peaks occurs associated with different sensory, cognitive and motor processes (see Luck 2005 for introduction and Gajewski et al. 2009 for advanced methodological issues). In particular, ERPs are related to processes such as memory, expectation, attention, decision making or response activation and allow investigation of these processes with an extremely high time resolution. By the concise measure of timing and intensity of such processes, differences in the sensory, cognitive and motor processing between young and old individuals can be identified (e.g. Hahn et al. 2010; Yordanova et al. 2004). Moreover, using ERPs subliminal changes or compensatory mechanisms can be detected (e.g. Wild-Wall et al. 2007, 2008). Event-related potentials can also be successfully applied to several clinical applications (e.g. Polich and Corey-Bloom 2005), road traffic (Schmidt et al. 2009) and occupational research (Gajewski et al. 2010b; Wild-Wall et al. 2009; Fig. 2). 

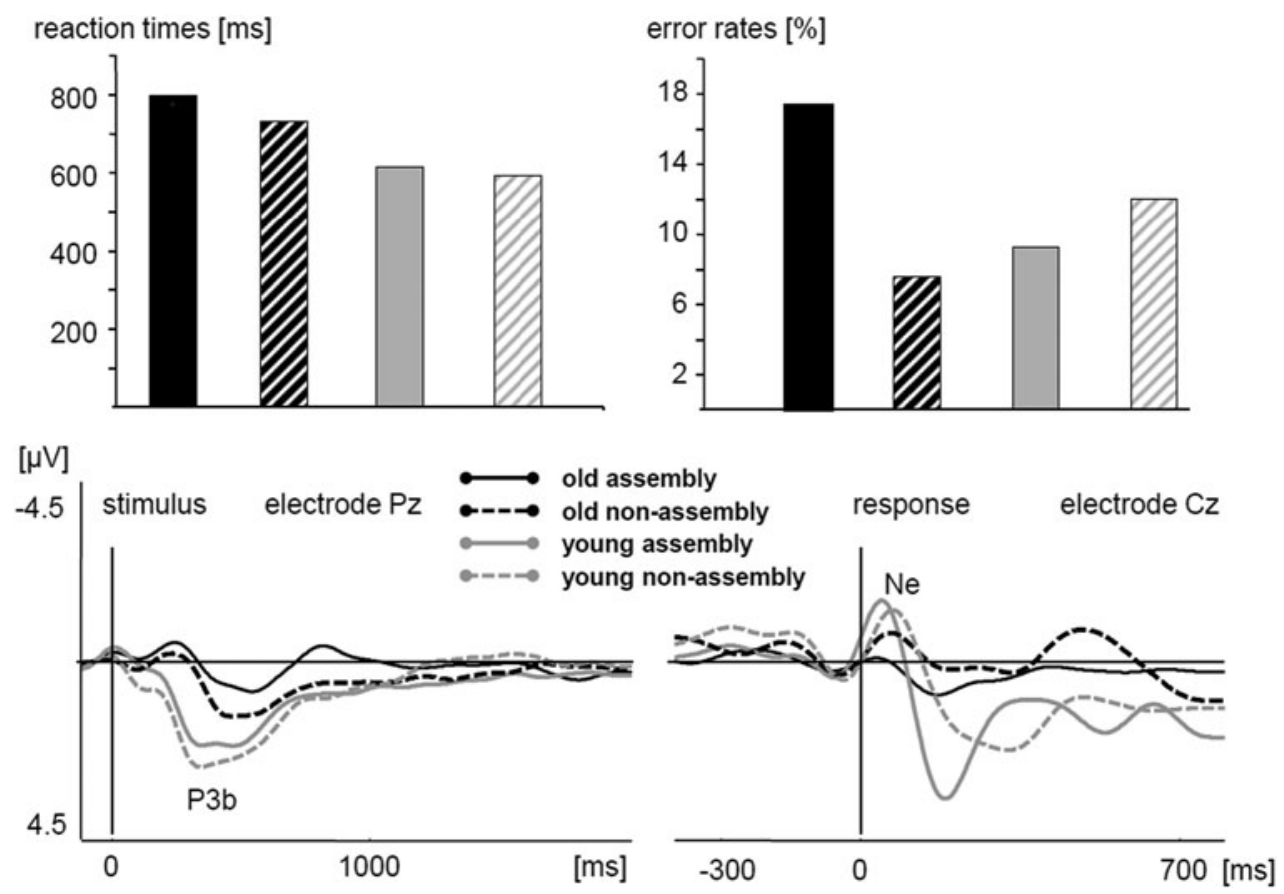

Fig. 3 Results of a PC-based cognitive test applied in the PFIFF study for the four participants groups (solid black: old assembly line, dotted black: old non-assembly line, solid gray: young assembly line, dotted gray: young non-assembly line). The test consisted of a long sequence of simple numerical categorization tasks. The participants memorized the task sequence in advance and switched among these tasks. Reaction times indicate the time elapsed from the presentation of a test stimulus on the screen and the button press after a correct stimulus categorization. Error rates indicate the mean number of erroneous responses.

\section{Applying the neurocognitive approach in an occupational context: the PFIFF project}

PFIFF is a program for improving cognitive abilities in older employees, and primarily aimed at older workers with unchallenging work demands (Freude et al. 2008, 2010; WildWall et al. 2009). The starting point of this project was a profound literature analysis that aimed to extract factors that may influence the central nervous system to improve fluid cognitive functions. Secondly, on the basis of this review a recommendation catalogue for older employees and workplace health management was prepared and implemented on an internet site for free access (www.pfiffprojekt.de). The third component of the project was a study that aimed at investigating fluid cognitive functions in older employees with low and high demanding work characteristics (see Gajewski et al. 2010b for details of the study). For this reason 91 participants of a big car factory were recruited. One half of participants were older workers (mean age 52), the other half were younger workers (mean age 22). One half of each aging group included employees with flexible and timely non-restricted work like service, maintenance and repair of machines, whereas the other half included workers from
As can be seen in the bar graphs, the older assembly-line participants showed the longest reaction times and clearly higher error rates than the other three groups due to loss of the correct task sequence. This suggests lower working memory performance that was also visible in the ERPs by reduced P3b amplitude (bottom left). The impaired error monitoring is reflected by the selective reduced amplitude of the error negativity in this group (Ne; bottom right). See Gajewski et al. (2010b) for further details

the timely restricted assembly and production. The workers participated in one 1.5-hour EEG-session which consisted of a series of computer-based cognitive tasks. These tasks aimed at investigating the status of the crucial fluid functions involved in a complex memory-based task-switching paradigm like working memory, task preparation, error processing, and assignment of cognitive resources to the task. Each of these functions was investigated by analyzing a specific ERP-component, indexing brain activity involved in the processing of the task. In particular, we focused on two brain potentials: the $\mathrm{P} 3 \mathrm{~b}$ and $\mathrm{Ne}$ (Fig. 3). The P3b is a large positive wave appearing 300 to 600 milliseconds after a stimulus onset with a parietal topography that was associated with allocation of cognitive resources (Kok 2001), working memory and stimulus-response coupling (Verleger et al. 2006). According to the context updating hypothesis of the $\mathrm{P} 3 \mathrm{~b}$ stimulus-related context, updating occurred when a model of the environment requires revision (Donchin and Coles 1988).

During execution of a task, an erroneous response may occur that is accompanied by a negative, frontocentral distributed ERP component- the error negativity (Ne; Falkenstein et al. 1991) which is thought to reflect early error de- 


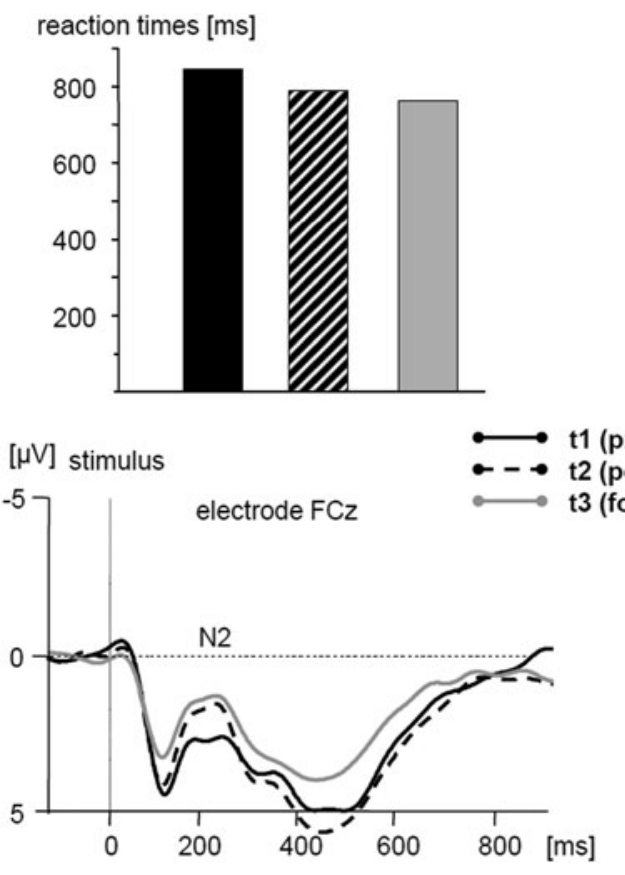

Fig. 4 Results of the PC-based cognitive test applied in the PFIFF2 study for the cognitive training group (unpublished data). Participants performed a memory-based task-switching test used in the previous PFIFF study (see the caption of Fig. 3). The test was applied before training ( $\mathrm{t} 1$, solid black), after 3 months of training ( $\mathrm{t} 2$, dotted black) and 3 months after the training was finished ( $\mathrm{t} 3$, solid grey). Reaction times did not change significantly across the three time points. Error rates before training ( $\mathrm{t} 1)$ were similar to the presented in Fig. 3. However, a clear decrease of error rates occurred after the training ( $t 2)$

tection. The $\mathrm{Ne}$ is seen as the result of a comparison process between the expected and the actual outcome, leading to behavioral readjustment and learning (Falkenstein et al. 2000; Holroyd and Coles 2002). It has also been shown that the $\mathrm{Ne}$ is smaller for older than younger participants, suggesting a weakening of action monitoring processes in older adults (Band and Kok 2000; Falkenstein et al. 2001).

As behavioral parameters, reaction times and error rates were analyzed. Generally, older participants responded slower than younger participants that support the wellknown age-related slowing (e.g. Salthouse 2000). However, in focus of the study was the comparison between workers at flexible and non-flexible workplaces. Flexibly working older employees were slower but more accurate than the younger workers. Importantly, they showed faster responses and lower error rates than the assembly-line older employees, particularly in a difficult memory-based version of the switching task. This difference in performance was accompanied by a number of electrophysiological findings, suggesting lower memory capacity (P3b; Kok 2001) and presumably as a consequence of this decline an impaired error detection (Ne; Falkenstein et al. 1991) which reflects a precondition for successful learning (e.g. Hol-
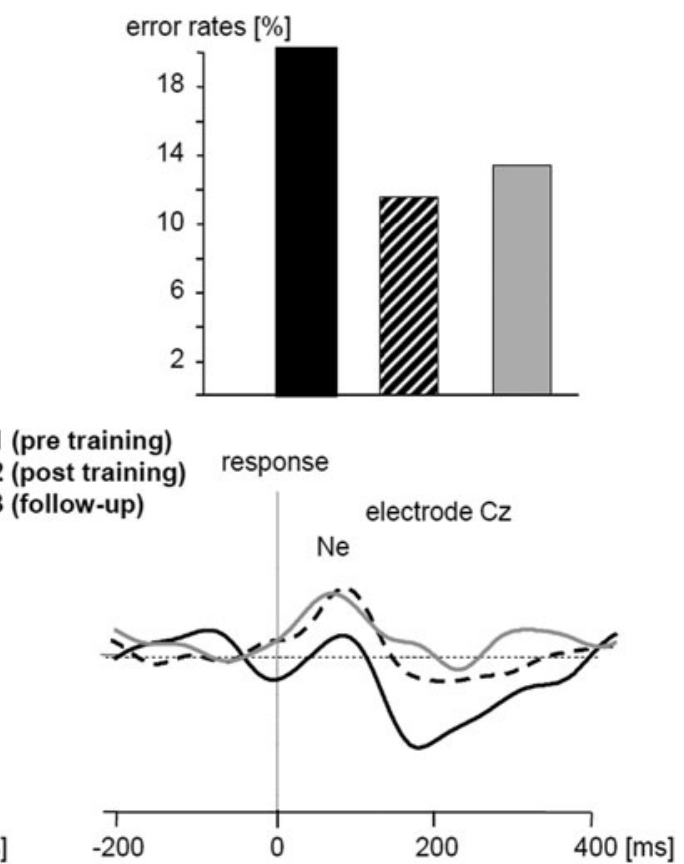

which persisted 3 months later (t3). Bottom left: Target-locked ERPs at the electrode FCz. The frontocentral negativity, the $\mathrm{N} 2$ associated with response selection process increased from $\mathrm{t} 1$ to $\mathrm{t} 2$ and remained stable from $\mathrm{t} 2$ to $\mathrm{t} 3$, suggesting more efficient decision after training. Bottom left: Response-locked ERPs in erroneous responses. The error negativity (Ne) was initially weak and similar to the observed in Fig. 3 but increased considerably after the training ( $\mathrm{t} 2$ ) and remained stable 3 months later. No effects were found for the waiting control groups between $\mathrm{t} 1$ and $\mathrm{t} 2$ (not depicted in the picture)

royd and Coles 2002). These results support the findings reported above, suggesting negative influence of unchallenging job characteristics on cognitive functions. Additionally, the ERPs show, in much more detail, which functions are impaired.

\section{Ameliorating cognitive decline in older workers: the PFIFF 2 project}

The aim of the second part of the PFIFF project was to try ameliorating the cognitive decline found in older assemblyline participants, as outlined above. To this end, some of the methods for improving fluid cognition that were extracted from the literature should be applied in the practice. One of the methods was a formal cognitive training found to be effective in improving cognitive functions (e.g. Kramer and Morrow 2008) and revealed to be beneficial for both behavioral parameters and brain activity in older age in our previous study (Gajewski et al. 2010a). The training was not focused on a particular cognitive function but aimed at affecting a broad spectrum of cognitive abilities. Thus, the formal cognitive training consisted of paper and pencil exercises (Mental Activation Training, MAT, Lehrl et al. 
1994) and a number of commercial and non-commercial computer-based exercises that were selected on the basis of their expected efficiency to improve different functions like attention, working memory, dual-task performance, inhibition, problem solving and task switching. The training period lasted 3 months, two sessions per week for 1.5 hours each. 120 middle-aged workers (mean age 47 years) of the assembly line and repetitive production sector participated in the study. The sample was subdivided into two groups with 60 workers each which completed the study successively. Each of the subgroups was randomly assigned to training- and waiting-control group that received combined cognitive and relaxation training first after the cognitive training group completed the training. Before, after the training, and three months later a number of psychometric paper and pencil and computer-based tasks was applied and the cortisol awaking response (CAR, Kudielka et al. 2007) was measured. The CAR refers to the increase in cortisol release over the first 30 minutes after awakening (Adam et al. 2006). The EEG was recorded in the second training group only.

Preliminary data show an improvement in a number of psychometric paper and pencil tests in the training group relative to the control group after the training. Particularly, the older participants with initially lower performance benefited clearly from the training. Importantly, the results from the memory-based task-switching paradigm depicted in Fig. 4 showed considerable improvements of cognitive performance, particularly a decrease of error rates, suggesting improved maintenance of a complex task sequence in working memory. The behavioral benefits were accompanied by a number of electrophysiological changes, like increase of a negative frontocentral activity (N2), associated with selection of a correct response in general (Gajewski et al. 2008) and resolution of interference during task switching (Gajewski et al. 2010c). Furthermore, a significant increase of error negativity $(\mathrm{Ne})$ associated with successful error monitoring was observed (Falkenstein et al. 1991). This pattern of results persisted even three months later after the training was finished. In contrast, no changes in the waiting control group were found at this time point. However, after this group received the combined cognitive and relaxation training, the same neurocognitive improvements were observed as in the cognitive training group only. Moreover, as a result of the relaxation training, a significantly reduced level of Cortisol in the CAR was found.

These findings suggest that formal cognitive training may indeed ameliorate cognitive decline that is also reflected in an improvement of brain activity. A combination of cognitive and relaxation training has beneficial effect on both the neurocognitive functions and stress responsibility.
Although no direct conclusions can be drawn from these results regarding the employability of the trainees, the observed improvements of cognition and emotion may enhance their learning ability, self-confidence and help to consolidate individual potential at work.

\section{Summary and concluding remarks}

This article provides a short overview about neurocognitive functioning in middle and older age. Particularly, we focused on fluid cognitive functions that are crucial for each type of occupation. It has been shown that the efficiency of these functions strongly varied between individuals. This variability is mainly due to genetic and environmental factors during the life history. More important, cognitive functions are to some extent modifiable even in older age. Recent neuroscientific literature suggests that middle-aged and older brains carry a high potential for neuronal plasticity that was neglected in the last decades. This fact implies that age-related decline can be attenuated or even diminished by an active interaction with the environment and healthpromoting activities. Physical exercise, nutrition, dietary restriction, challenging cognitive activities and formal cognitive training are methods which are capable to enhance the brain activity and to improve fluid cognition of elderly people. In contrast, decline of cognitive functions can be accelerated by adverse environmental and/or occupational factors like monotonous, unchallenging work, shift work and reluctance or lack of possibilities for advance education. In fact, combination of these factors is not unusual in the working area. The results of the first part of the PFIFF project revealed some cognitive declines associated with impairments of brain activity in older assembly-line workers which are probably due to combination of these awkward factors.

This result was also the starting point of the second part of the PFIFF study that included formal cognitive training for middle-aged assembly-line workers. The results indicate improvement of some of the fluid cognitive functions which were found to be impaired in the first phase of the project. The improvements were also visible in enhanced brain activity and lower stress reactivity than before the training and persisted at least three months later. This suggests that cognition and brain activity can be permanently stimulated even by a relatively short intervention.

These person-centered interventions appear to be useful -both for the employees and the employers-because they improve mental fitness and, hence, the employability. Therefore, their broader implementation in the future should be pursued. However, the interventions can be successful only if the employers support such activities in their factories and companies. Moreover, situation-centered interventions, such 
as better ergonomics and improved supervisor behavior are necessary. This shows the responsibility of the employers and management to create and maintain a cognitively efficient and innovative workforce.

Founding The research reported in this article was conducted as a PFIFF-Project (program for improving cognitive abilities in older employees) within a framework of INQA-New Quality of Work, which was funded by Federal Ministry of Labour and Social Affairs, BMAS.

\section{Executive summary}

Due to demographic change the number of employees will decrease and their age will continuously increase. Thus, western countries will be faced with huge challenges as a smaller and older workforce has to produce more to maintain economic growth and defy global competition. This may be problematic as aging is accompanied by declines in sensory, motor and cognitive functions. Particularly, the so-called fluid cognitive functions which are crucial for employability are often affected already in middle age. However, the course of the fluid cognitive status in aging may proceed very differently due to individual history, experiences and activities during the lifespan. Current neuroscientific findings suggest preserved neuronal plasticity in aging brains that can be stimulated by factors like nutrition, education, social engagement, new experiences, physical activity and work demands. Therefore, age-related cognitive declines can be compensated by a number of activities. The main part of the article analyzes the relationship between type of work and fluid cognitive functions in more detail. The results of the first part of the PFIFF-project showed that cognitive decline may be accelerated by long-lasting unchallenging work and hence may occur already in middle age. On the other hand, timely flexible and varying work may successfully compensate age-related decline in cognition. In the second part of PFIFF a 3-month program consisting of a supervised PC-based cognitive training was implemented in a group of 120 assembly-line employees with highly repetitive work. Half of the trainees received additionally relaxation and stress management training. The results provide evidence that cognitive training improves cognitive abilities and brain processes in older employees with repetitive work, who were found to be impaired in the first part of the project. Moreover, lower Cortisol level after the stress management training suggests improved stress resiliency of the trainees. Hence the combined training appears to be suitable to improve mental and emotional fitness of elderly employees with unfavorable work conditions and demonstrates their preserved brain plasticity. Hence, the PFIFF project can be seen as a part of a comprehensive program for promoting mental fitness in older employees which requires broader implementation in the future to enhance individual health and employability.

\section{Kurzfassung}

Aufgrund des demographischen Wandels wird die Anzahl der Beschäftigten abnehmen und ihr Alter kontinuierlich zunehmen. Deshalb werden die westlichen Länder mit enormen Herausforderungen konfrontiert, wie eine kleinere und ältere Arbeiterschaft das ökonomische Wachstum sichern und dem globalen Wettbewerb standhalten kann. Dies wird problematisch, da das Alter mit Verschlechterung sensorischer, motorischer, und kognitiver Funktionen einhergeht. Insbesondere die sogenannten fluiden kognitiven Funktionen, die kritisch für die Beschäftigungsfähigkeit sind, sind häufig bereits im mittleren Erwachsenenalter verändert. Der Verlauf der fluiden kognitiven Funktionen ist jedoch sehr unterschiedlich aufgrund individueller Vorgeschichte, Erfahrungen und Aktivitäten im Laufe des Lebens. Die aktuellen neurowissenschaftlichen Erkenntnisse weisen auf weitgehend erhaltene neuronale Plastizität der alternden Gehirne hin, die durch Ernährung, Bildung, soziales Engagement, neue Herausforderungen, körperliche Aktivität oder die Art der Arbeit stimuliert werden kann. Daraus folgt, dass altersbedingte kognitive Defizite durch unterschiedliche Aktivitäten kompensiert werden können. Der Hauptteil des Artikels analysiert detailliert den Zusammenhang zwischen kognitiven Funktionen und der Art der Arbeit. Die Ergebnisse der ersten Phase des Projektes PFIFF zeigen, dass kognitive Defizite und Veränderungen von Hirnfunktionen durch langjährige, monotone Arbeit beschleunigt werden und bereits im mittleren Erwachsenenalter auftreten können. Auf der anderen Seite, zeigte sich, dass zeitlich flexible und abwechslungsreiche Arbeit den altersbedingten kognitiven Abbau erfolgreich kompensieren kann. In der zweiten Phase wurde bei 120 Teilnehmern mit repetitiver Montagearbeit ein trainergeführtes, PC-gestütztes kognitives Training über einen Zeitraum von drei Monaten durchgeführt. Die Hälfte der Teilnehmer erhielt zusätzlich Entspannungs- und Stressmanagementtraining. Die Ergebnisse zeigen, dass das Programm kognitive Funktionen und Hirnprozesse verbesserte, die im ersten Teil des Projektes deutliche Defizite aufwiesen. Darüber hinaus reduzierte sich der Cortisolspiegel durch das Stressmanagementtraining, was auf eine verbesserte Stressresilienz der Teilnehmer hinweist. Insgesamt scheint der kombinierte Trainingsansatz geeignet, die mentale und emotionale Fitness älterer Beschäftigter mit ungünstigen Arbeitsbedingungen zu verbessern, und demonstriert zugleich ihre erhaltene Hirnplastizität. Insgesamt kann das Projekt PFIFF als Teil eines umfassenden Ansatzes zum Erhalt und zur Förderung der mentalen Gesundheit älterer Arbeitnehmer verstanden 
werden, die in der Zukunft großflächig implementiert werden sollte, um Gesundheit und Beschäftigungsfähigkeit zu verbessern.

Acknowledgements We thank Dr. Gabrielle Freude for supervision, Dr. Thomas Koiky and Dieter Welwei for assistance in organizing the study, Claudia Wipking, Ines Mombrei, Christiane Westedt and Rita Willemssen for conducting the testing. We wish also to thank Prof. Dr. Alexa Franke, Rita Pfeiffer, Catharina Stahn and Maibritt Witte for planning and implementing the trainings and Ludger Blanke for developing the software and technical support.

\section{References}

Adam, E.K., Hawkley, L.C., Kudielka, B.M., Cacioppo, J.T.: Day-today dynamics of experience-cortisol associations in a populationbased sample of older adults. Proc. Natl. Acad. Sci. USA 103(45), 17058-17063 (2006)

Alvarado, B.E., Zunzunegui, M.V., del Ser, T., Beland, F.: Cognitive decline is related to education and occupation in a Spanish elderly cohort. Aging Clin. Exp. Res. (Testo Stamp.) 14(2), 132142 (2002)

Andel, R., Crowe, M., Pedersen, N.L., Mortimer, J., Crimmins, E., Johansson, B., Gatz, M.: Complexity of work and risk of Alzheimer's disease: a population-based study of Swedish twins. J. Gerontol. B Psychol. Sci. Soc. Sci. 60(5), 251-258 (2005)

Ansiau, D., Wild, P., Niezborala, M., Rouch, I., Marquié, J.C.: Effects of working conditions and sleep of the previous day on cognitive performance. Appl. Ergon. 39(1), 99-106 (2008)

Arendash, G.W., Garcia, M.F., Costa, D.A., Cracchiolo, J.R., Wefes, I.M., Potter, H.: Environmental enrichment improves cognition in aged Alzheimer's transgenic mice despite stable beta-amyloid deposition. Neuroreport 15(11), 1751-1754 (2004)

Ball, K., Edwards, J.D., Ross, L.A.: The impact of speed of processing training on cognitive and everyday functions. J. Gerontol. B Psychol. Sci. Soc. Sci. 62(1), 19-31 (2007)

Baltes, P.B.: Theoretical propositions of life-span developmental psychology: on the dynamics between growth and decline. Dev. Psychol. 23(5), 611-626 (1987)

Baltes, P.B., Graf, P.: Psychological aspects of aging: facts and frontiers. In: Magnusson, D. (ed.) Individual Development over the Lifespan: Biological and Psychosocial Perspectives. Cambridge University Press, New York (1996)

Baltes, P.B., Lindenberger, U.: On the range of cognitive plasticity in old age as a function of experience: 15 years of intervention research. Behav. Ther. 19(3), 283-300 (1988)

Baltes, P.B., Lindenberger, U.: Emergence of a powerful connection between sensory and cognitive functions across the adult lifespan: a new window to the study of cognitive aging? Psychol. Aging 12(1), 12-21 (1997)

Band, G.P., Kok, A.: Age effects on response monitoring in a mentalrotation task. Biol. Psychol. 51(2-3), 201-221 (2000)

Bartzokis, G.: Age-related myelin breakdown: a developmental model of cognitive decline and Alzheimer's disease. Neurobiol. Aging 25(1), 5-18 (2004) (author reply, pp. 49-62)

Basak, C., Boot, W.R., Voss, M.W., Kramer, A.F.: Can training in a real-time strategy video game attenuate cognitive decline in older adults? Psychol. Aging 23(4), 765-77 (2008)

Baune, B.T., Ponath, G., Rothermundt, M., Riess, O., Funke, H., Berger, K.: Association between genetic variants of IL-1beta, IL6 and TNF-alpha cytokines and cognitive performance in the elderly general population of the MEMO-study. Psychoneuroendocrinology, 33(1), 68-76 (2008)
Baur, J.A., Sinclair, D.A.: Therapeutic potential of resveratrol: the in vivo evidence. Nat. Rev., Drug Discov. 5(6), 493-506 (2006)

Becic, E., Boot, W.R., Kramer, A.F.: Training older adults to search more effectively: scanning strategy and visual search in dynamic displays. Psychol. Aging 23(2), 461-466 (2008)

Bielak, A.A., Hughes, T.F., Small, B.J., Dixon, R.A.: It's never too late to engage in lifestyle activities: significant concurrent but not change relationships between lifestyle activi-ties and cognitive speed. J. Gerontol. B Psychol. Sci. Soc. Sci. 62(6), 331-339 (2007)

Bherer, L., Kramer, A.F., Peterson, J.S., Colcombe, S., Erickson, K., Becic, E.: Training effects on dual-task performance: are there age-related differences in plasticity of attentional control? Psychol. Aging 20(4), 695-709 (2005)

Bhardwaj, R.D., Curtis, M.A., Spalding, K.L., Buchholz, B.A., Fink, D., Bjork-Eriksson, T., Nordborg, C., Gage, F.H., Druid, H., Eriksson, P.S., Frisen, J.: Neocortical neurogenesis in humans is restricted to development. Proc. Natl. Acad. Sci. USA 103(33), 12564-12568 (2006)

Blakemore, S.J., Choudhury, S.: Development of the adolescent brain: Implications for executive function and social cognition. J. Child Psychol. Psychiatry 47(3-4), 296-312 (2006)

Bosma, H., van Boxtel, M.P., Ponds, R.W., Houx, P.J., Burdorf, A., Jolles, J.: Mental work demands protect against cognitive impairment: MAAS prospective cohort study. Exp. Aging Res. 29(1), 33-45 (2002)

Burdette, J.H., Laurienti, P.J., Espeland, M.A., Morgan, A., Telesford, Q., Vechlekar, C.D., Hayasaka, S., Jennings, J.M., Katula, J.A., Kraft, R.A., Rejeski, W.J.: Using network science to evaluate exercise-associated brain changes in older adults. Front. Aging Neurosci. 7, 2-23 (2010)

Cabeza, R.: Hemispheric asymmetry reduction in older adults: the HAROLD model. Psychol. Aging 17(1), 85-100 (2002)

Cabeza, R., Anderson, N.D., Locantore, J.K., McIntosh, A.R.: Aging gracefully: compensatory brain activity in high-performing older adults. Neuroimage 17(3), 1394-1402 (2002)

Cabeza, R., Kingstone, A.: Handbook of Functional Neuroimaging of Cognition, 2nd edn. MIT Press, Cambridge (2006)

Caserta, R.J., Young, J., Janelle, C.M.: Old dogs, new tricks: Training the perceptual skills of senior tennis players. J. Sport Exerc. Psychol. 29(4), 479-97 (2007)

Cassavaugh, N., Kramer, A.F.: Transfer of computer-based cognitive training to simulated driving in older adults. Appl. Ergon. 40(5), 943-952 (2009)

Cattell, R.B.: Theory of fluid and crystallized intelligence: a critical experiment. J. Educ. Psychol. 54(1), 1-22 (1963)

Colcombe, S., Kramer, A.F.: Fitness effects on the cognitive function of older adults: a meta-analytic study. Psychol. Sci. 14(2), 125130 (2003)

Colcombe, S.J., Kramer, A.F., Erickson, K.I., Scalf, P., McAuley, E., Cohen, N.J., Webb, A., Jerome, G.J., Marquez, D.X., Elavsky, S.: Cardiovascular fitness, cortical plasticity, and aging. Proc. Natl. Acad. Sci. USA 101(9), 3316-3321 (2004)

Colsher, P.L., Wallace, R.B.: Longitudinal application of cognitive function measures in a defined population of community-dwelling elders. Ann. Epidemiol. 1(3), 215-230 (1991)

Costa, G.: The impact of shift and night work on health. Appl. Ergon. 27(1), 9-16 (1996)

Craik, F.I.M., Salthouse, T.A. (eds.): The Handbook of Aging and Cognition, 2nd edn. Erlbaum, Mahwah (2000)

Curtis, M.A., Eriksson, P.S., Faull, R.L.: Progenitor cells and adult neurogenesis in neurodegenerative diseases and injuries of the basal ganglia. Clin. Exp. Pharmacol. Physiol. 34(5-6), 528-532 (2007)

Davis, S.W., Dennis, N.A., Daselaar, S.M., Fleck, M.S., Cabeza, R.: Que PASA? The posterior-anterior shift in aging. Cereb. Cortex 18(5), 1201-1209 (2008) 
De Blasi, S., Montesanto, A., Martino, C., Dato, S., De Rango, F., Bruni, A.C., Mari, V., Feraco, E., Passarino, G.: APOE polymorphism affects episodic memory among non-demented elderly subjects. Exp. Gerontol. 44(3), 224-227 (2009)

Donchin, E., Coles, M.G.H.: Is the P300 component a manifestation of context updating? Behav. Brain Sci. 11 (1988)

Edwards, J.D., Myers, C., Ross, L.A., Roenker, D.L., Cissell, G.M., McLaughlin, A.M., Ball, K.K.: The longitudinal impact of cognitive speed of processing training on driving mobility. Gerontologist 49(4), 485-494 (2009)

Elbert, T., Pantev, C., Wienbruch, C., Rockstroh, B., Taub, E.: Increased cortical representation of the fingers of the left hand in string players. Science 270(5234), 305-307 (1995)

Erickson, K.I., Kim, J.S., Suever, B.L., Voss, M.W., Francis, B.M., Kramer, A.F.: Genetic contributions to age-related decline in executive function: a 10-year longitudinal study of COMT and BDNF polymorphisms. Front. Human Neurosci. 2, 11 (2008)

Erickson, K.I., Prakash, R.S., Voss, M.W., Chaddock, L., Heo, S., McLaren, M., Pence, B.D., Martin, S.A., Vieira, V.J., Woods, J.A., McAuley, E., Kramer, A.F.: Brain-derived neurotrophic factor is associated with age-related decline in hippocampal volume. J. Neurosci. 30(15), 5368-5375 (2010)

Erickson, K.I., Voss, M.W., Prakash, R.S., Basak, C., Szabo, A., Chaddock, L., Kim, J.S., Heo, S., Alves, H., White, S.M., Wojcicki, T.R., Mailey, E., Vieira, V.J., Martin, S.A., Pence, B.D., Woods, J.A., McAuley, E., Kramer, A.F.: Exercise training increases size of hippocampus and improves memory. Proc. Natl. Acad. Sci. USA 108(7), 3017-3022 (2011)

Eriksson, P.S., Perfilieva, E., Bjork-Eriksson, T., Alborn, A.M., Nordborg, C., Peterson, D.A., Gage, F.H.: Neurogenesis in the adult human hippocampus. Nat. Med. 4(11), 1313-1317 (1998)

Falkenstein, M.: Geistig vorsorgen: 7 goldene Regeln. So bleiben Sie mental fit - und schützen sich vor Alzheimer! Gehirn Geist 10, 42-47 (2008)

Falkenstein, M., Poschadel, S.: Altersgerechtes Autofahren. Wirtschaftspsychologie 3, 62-71 (2008)

Falkenstein, M., Hohnsbein, J., Hoormann, J.: Effects of crossmodal divided attention on late ERP components. II. Error processing in choice reaction tasks. Electroencephalogr. Clin. Neurophysiol. 78(6), 447-455 (1991)

Falkenstein, M., Hoormann, J., Christ, S., Hohnsbein, J.: ERP components on reaction errors and their functional significance: a tutorial. Biol. Psychol. 51(2-3), 87-107 (2000)

Falkenstein, M., Hoormann, J., Hohnsbein, J.: Changes of error-related ERPs with age. Exp. Brain Res. 138(2), 258-262 (2001)

Flake, C.: Psychische Belastungen in der Arbeitswelt erkennen und bewerten. In: Flake, C., Freigang-Bauer, I., Gröben, F., Wenchel, K.T. (eds.) Psychischer Stress in der Arbeitswelt. Erkennen - mindern - bewältigen. RKW-Verlag, Eschborn (2001)

Flood, D., Coleman, P.: Neuron numbers and size in ageing brain: comparison of human, monkey and rodent data. Neurobiol. Aging 9(5-6), 453-463 (1988)

Freude, G., Falkenstein, M., Wild-Wall, N., Gajewski, P., Zülch, J., Stahn, C., Sturm, P., Pech, E.: Geistig fit im Beruf! Wege für ältere Arbeitnehmer zur Stärkung der grauen Zellen. INQA, Initiative Neue Qualität der Arbeit. BauA, Dortmund (2008)

Freude, G., Falkenstein, M., Zülch, J. (eds.): Förderung und Erhalt intellektueller Fähigkeiten für ältere Arbeitnehmer. Abschlussbericht des Projekts "Pfiff". Dortmund: Initiative Neue Qualität der Arbeit (INQA), INQA-Bericht, Nr. 39 (2010)

Frick, K.M., Fernandez, S.M.: Enrichment enhances spatial memory and increases synaptophysin levels in aged female mice. Neurobiol. Aging 24(4), 615-626 (2003)

Frieling, E.B., Weichel, J.: Ältere Beschäftigte in gewerblichindustriellen Tätigkeiten - ausgewählte Ergebnisse und Handlungsfelder am Beispiel der Montage. Wirtschaftspsychologie, Themenheft „Alter und Arbeit“ 10(3), 120-128 (2008)
Gajewski, P.D., Stoerig, P., Falkenstein, M.: ERP-correlates of response selection in a response conflict paradigm. Brain Res. 1189, 127-134 (2008)

Gajewski, P.D., Wild-Wall, N., Hoffmann, S., Falkenstein, M.: Ereigniskorrelierte Potenziale: Ansatz, Parametrisierung und Analyseverfahren. Neuroforum 4, 124-129 (2009)

Gajewski, P.D., Wipking, C., Falkenstein, M., Gehlert, T.: Dortmunder Altersstudie: Studie zur Förderung der Hirnleistungsfähigkeit bei Älteren. Berlin: GDV, Unfallforschung der Versicherer, Gesamtverband der Deutschen Versicherungswirtschaft, Forschungsbericht, VV04 (2010a)

Gajewski, P.D., Wild-Wall, N., Falkenstein, M., Schapkin, S., Erdmann, U., Freude, G.: Effects of aging and job demands on cognitive flexibility assessed by task switching: an electrophysiological study. Biol. Psychol. 85(2), 187-199 (2010b)

Gajewski, P.D., Kleinsorge, T., Falkenstein, M.: Electrophysiological correlates of residual switch costs. Cortex 46(9), 1138-1148 (2010c)

Gajewski, P.D., Hengstler, J., Golka, K., Falkenstein, M., Beste, C.: The Met-allele of the BDNF Val66Met polymorphism enhances task switching in elderly. Neurobiol. Aging (2011, in press)

Gazzaley, A., Cooney, J.W., Rissman, J., D’Esposito, M.: Top-down suppression deficit underlies working memory impairment in normal aging. Nat. Neurosci. 8(10), 1298-1300 (2005)

Gopher, D., Weil, M., Bareket, T.: Transfer of skill from a computer game trainer to flight. Hum. Factors 36(3), 387-405 (1994)

Grady, C.L.: Age-related changes in cortical blood flow activation during perception and memory. Ann. N.Y. Acad. Sci. 777, 14-21 (1996)

Grady, C.L., McIntosh, A.R., Craik, F.I.: Task-related activity in prefrontal cortex and its relation to recognition memory performance in young and old adults. Neuropsychologia 43(10), 1466-1481 (2005)

Green, C., Bavelier, D.: Action video game modifies visual selective attention. Nature 423(6939), 534-537 (2003)

Greenwood, P.M.: Functional plasticity in cognitive aging: review and hypothesis. Neuropsychology 21(6), 657-673 (2007)

Greenwood, P.M., Parasuraman, R.: Neuronal and cognitive plasticity: a neurocognitive framework for ameliorating cognitive aging. Front. Aging Neurosci. 2, 150 (2010)

Greenwood, C.E., Winocur, G.: High-fat diets, insulin resistance and declining cognitive function. Neurobiol. Aging 26, 42-45 (2005) (Suppl. 1)

Grossmann, I., Na, J., Varnum, M.E., Park, D.C., Kitayama, S., Nisbett, R.E.: Reasoning about social conflicts improves into old age. Proc. Natl. Acad. Sci. USA 107(16), 7246-7250 (2010)

Gur, R.C., Mozley, P.D., Resnick, S.M., Gottlieb, G.L., Kohn, M., Zimmerman, R., Herman, G., Atlas, S., Grossman, R., Berretta, D.: Gender differences in age effect on brain atrophy measured by magnetic resonance imaging. Proc. Natl. Acad. Sci. USA 88(7), 2845-2849 (1991)

Hahn, M., Falkenstein, M., Wild-Wall, N.: Age-related performance differences in compensatory tracking under a dual task condition. Occup. Ergon. 9, 75-86 (2010)

Haus, E., Smolensky, M.: Biological clocks and shift work: Circadian dysregulation and potential long-term effects. Canc. Causes Contr. 17(4), 489-500 (2006)

Hillman, C.H., Erickson, K.I., Kramer, A.F.: Be smart, exercise your heart: exercise effects on brain and cognition. Nat. Rev., Neurosci. 9(1), 58-65 (2008)

Holroyd, C.B., Coles, M.G.H.: The neural basis of human error processing: reinforcement learning, dopamine, and the error-related negativity. Psychol. Rev. 109(4), 679-709 (2002)

Hultsch, D.F., Hertzog, C., Small, B.J., Dixon, R.A.: Use it or lose it: engaged lifestyle as a buffer of cognitive decline in aging? Psychol. Aging, 14(2), 245-263 (1999) 
Hultsch, D.F., MacDonald, S.W.S.: Intraindividual variability in performance as a theoretical window onto cognitive aging. In: Dixon, R.A., et al. (eds.) New Frontiers in Cognitive Aging, pp. 65-88. Oxford University Press, Oxford (2004)

Sockoll, I.: Psychische Gesundheit im Erwerbsleben. IGA Fakten 1. Initiative Gesundheit und Arbeit, BKK Bundesverband (2009)

Ilmarinen, J.: The ageing workforce-challenges for occupational health. Occup. Med 56(6), 362-364 (2006)

James, W.: The Principles of Psychology. Dover, London (1890)

Jaeggi, S.M., Buschkuehl, M., Jonides, J., Perrig, W.J.: Improving fluid intelligence with training on working memory. Proc. Natl. Acad. Sci. USA 105(19), 6829-6833 (2008)

Kang, J.H., Ascherio, A., Grodstein, F.: Fruit and vegetable consumption and cognitive decline in aging women. Ann. Neurol. 57(5), 713-720 (2005)

Karbach, J., Kray, J.: How useful is executive control training? Age differences in near and far transfer of task-switching training. Dev. Sci. 12(6), 978-990 (2009)

Kempermann, G., Kuhn, H.G., Gage, F.H.: More hippocampal neurons in adult mice living in an enriched environment. Nature 386(6624), 493-495 (1997)

Klusmann, V., Evers, A., Schwarzer, R., Schlattmann, P., Reischies, F.M., Heuser, I., Dimeo, F.C.: Complex mental and physical activity in older women and cognitive performance: a 6-month randomized controlled trial. J. Gerontol. A Bio. Sci. Med. Sci. 65(6), 680-688 (2010)

Kok, A.: On the utility of P3 amplitude as a measure of processing capacity. Psychophysiology 38(3), 557-577 (2001)

Kramer, A.F., Erickson, K.I.: Capitalizing on cortical plasticity: influence of physical activity on cognition and brain function. Trends Cogn. Sci. 11(8), 342-348 (2007)

Kramer, A.F., Erickson, K.I., Colcombe, S.J.: Exercise, cognition, and the aging brain. J. Appl. Physiol. 101(4), 1237-1242 (2006)

Kramer, A.F., Gopher, D., Hahn, S.: Aging and executive control. Nature 400(6743), 112-135 (1999)

Kramer, A.F., Madden, D.: Attention. In: Craik, F.I.M., Salthouse, T.A. (eds.) The Handbook of Aging and Cognition. 3, pp. 189-249. Lawrence Erlbaum, Hillsdale (2008)

Kramer, A.F., Morrow, D.: Cognitive training and expertise. In: D. Park, N. Schwarz (eds) Cognitive Aging: A Primer, 2nd edn., Psychology Press, New York (2008)

Kray, J., Lindenberger, U.: Adult age differences in task switching. Psychol. Aging 15(1), 126-147 (2000)

Kudielka, B.M., Buchtal, J., Uhde, A., Wüst, S.: Circadian cortisol profiles and psychological self-reports in shift workers with and without recent change in the shift rotation system. Biol. Psychol. 74(1), 92-103 (2007)

Lee, Y., Back, J.H., Kim, J., Byeon, H.: Multiple Socioeconomic Risks and Cognitive Impairment in Older Adults. Dement. Geriatr. Cogn. Disord. 29(6), 523-529 (2010)

Lehrl, S., Lehrl, M., Weickmann, E.: MAT Gehirnjogging, Einführung in das Mentale AktivierungsTraining. Vless Verlag, Ebersberg (1994)

Lemaitre, H., Mattay, V.S., Sambataro, F., Verchinski, B., Straub, R.E., Callicott, J.H., Kittappa, R., Hyde, T.M., Lipska, B.K., Kleinman, J.E., McKay, R., Weinberger, D.R.: Genetic variation in FGF20 modulates hippocampal biology. J. Neurosci. 30(17), 5992-5997 (2010)

Lenhardt, U.: Gesundheitsförderung. Rahmenbedingungen und Entwicklungsstand. Soz.wiss. Berufsprax. 28(1), 5-17 (2005)

Lessmann, V., Gottmann, K., Malcangio, M.: Neurotrophin secretion: current facts and future prospects. Prog. Neurobiol. 69(5), 341374 (2003)

Luck, S.J.: An Introduction to the Event-Related Potential Technique. MIT Press, Cambridge (2005)
Madden, D.J., Gottlob, L.R., Allen, P.A.: Adult age differences in visual search accuracy: attentional guidance and target detectability. Psychol. Aging 14(4), 683-694 (1999)

Marquié, J.C., Duarte, L.R., Bessieres, P., Dalm, C., Gentil, C., Ruidavets, B.: Higher mental stimulation at work is associated with improved cognitive functioning in both young and older workers. Ergonomics 53(11), 1287-1301 (2010)

Masliah, E., Crews, L., Hansen, L.: Synaptic remodeling during aging and in Alzheimer's disease. J. Alzheimer's Dis. 9, 91-99 (2006) (3 Suppl.)

Milgram, N., Siwak-Tapp, C., Araujo, J., Head, E.: Neuroprotective effects of cognitive enrichment. Ageing Res. Rev. 5(3), 354-369 (2006)

Morrison, J.H., Hof, P.R.: Life and death of neurons in the aging brain. Science 278(5337), 412-419 (1997)

Park, D., Reuter-Lorenz, P.A.: The adaptive brain: aging and neurocognitive scaffolding. Ann. Rev. Psychol. 60, 173-196 (2009)

Pereira, A.C., Huddleston, D.E., Brickman, A.M., Sosunov, A.A., Hen, R., McKhann, G.M., Sloan, R., Gage, F.H., Brown, T.R., Small, S.A.: An in vivo correlate of exercise-induced neurogenesis in the adult dentate gyrus. Proc. Natl. Acad. Sci. USA 104(13), 56385643 (2007)

Pichora-Fuller, M.K., Schneider, B.A., Daneman, M.: How young and old adults listen to and remember speech in noise. J. Acoust. Soc. Am. 97(1), 593-608 (1995)

Polich, J., Corey-Bloom, J.: Alzheimer's disease and P300: review and evaluation of task and modality. Curr. Alzheimer Res. 2(5), 515525 (2005)

Pontifex, M.B., Hillman, C.H., Fernhall, B., Thompson, K.M., Valentini, T.A.: The effect of acute aerobic and resistance exercise on working memory. Med. Sci. Sports Exerc. 41(4), 927-934 (2009)

Potter, G.G., Helms, M.J., Plassman, B.L.: Associations of job demands and intelligence with cognitive performance among men in late life. Neurology 70(19), 1803-1808 (2008)

Rampon, C., Jiang, C.H., Dong, H., Tang, Y.P., Lockhart, D.J., Schultz, P.G., Tsien, J.Z., Hu, Y.: Effects of environmental enrichment on gene expression in the brain. Proc. Natl. Acad. Sci. USA 97(23), 12880-12884 (2000)

Raz, N.: Aging of the brain and its impact on cognitive performance: integration of structural and functional findings. In: Craik, F.I.M., Salthouse, T.A. (eds.) Handbook of Aging and Cognition, 2nd edn. pp. 1-90. Erlbaum, Mahwah (2000)

Reuter-Lorenz, P.A., Jonides, J., Smith, E.E., Hartley, A., Miller, A., Marshuetz, C., Koeppe, R.A.: Age differences in the frontal lateralization of verbal and spatial working memory revealed by PET. J. Cogn. Neurosci. 12(1), 174-187 (2000)

Rouch, I., Wild, P., Ansiau, D., Marquié, J.C.: Shiftwork experience, age and cognitive performance. Ergonomics 48(10), 1282-1293 (2005)

Salthouse, T.A.: Aging and measures of processing speed. Biol. Psychol. 54(1-3), 35-54 (2000)

Salthouse, T.A.: When does age-related cognitive decline begin? Neurobiol. Aging 30(4), 507-514 (2009)

Schmidt, E.A., Schrauf, M., Simon, M., Fritzsche, M., Buchner, A., Kincses, W.E.: Drivers' misjudgement of vigilance state during prolonged monotonous daytime driving. Accid. Anal. Prev. 41(5), 1087-1093 (2009)

Schooler, C., Mulatu, M.S.: The reciprocal effects of leisure time activities and intellectual functioning in older people: a longitudinal analysis. Psychol. Aging 16(3), 466-482 (2001)

Schooler, C., Mulatu, M.S., Oates, G.: The continuing effects of substantively complex work on the intellectual functioning of older workers. Psychol. Aging 14(3), 483-506 (1999)

Singh-Manoux, A., Richards, M., Marmot, M.: Leisure activities and cognitive function in middle age: evidence from the Whitehall II study. J. Epidemiol. Community Health 57(11), 907-913 (2003) 
Spreng, R., Wojtowicz, M., Grady, C.L.: Reliable differences in brain activity between young and old adults: a quantitative metaanalysis across multiple cognitive domains. Neurosci. Biobehav. Rev. 34(8), 1178-1194 (2010)

Springer, M.V., McIntosh, A.R., Winocur, G., Grady, C.L.: The relation between brain activity during memory tasks and years of education in young and older adults. Neuropsychology 19(2), 181$192(2005)$

Staudinger, U.M., Heidemeier, H.: Altern, Bildung und lebenslanges Lernen. Wissenschaftliche Verlagsgesellschaft, Stuttgart (2009)

Stern, Y.: Cognitive reserve. Neuropsychologia 47(10), 2015-2028 (2009)

Stern, Y., Gurland, B., Tatemichi, T.K., Tang, M.X., Wilder, D., Mayeux, R.: Influence of education and occupation on the incidence of Alzheimer's disease. JAMA 271(13), 1004-1010 (1994)

Swaab, D.F., Bao, A.M.: (Re-)activation of neurons in aging and dementia: Lessons from the hypothalamus. Exp. Gerontol. 46(2-3), 178-184 (2011)

Van Petten, C.: Relationship between hippocampal volume and memory ability in healthy individuals across the lifespan: review and meta-analysis. Neuropsychologia 42(10), 1394-1413 (2004)

Van Petten, C., Plante, E., Davidson, P.S., Kuo, T.Y., Bajuscak, L., Glisky, E.L.: Memory and executive function in older adults: relationships with temporal and prefrontal gray matter volumes and white matter hyperintensities. Neuropsychologia 42(10), 13131335 (2004)

van Praag, H., Kempermann, G., Gage, F.H.: Running increases cell proliferation and neurogenesis in the adult mouse dentate gyrus. Nat. Neurosci. 2(3), 266-270 (1999)

van Praag, H., Shubert, T., Zhao, C., Gage, F.H.: Exercise enhances learning and hippocampal neurogenesis in aged mice. J. Neurosci. 25(38), 8680-8685 (2005)

Verghese, J., Cuiling, W., Katz, M.J., Sanders, A., Lipton, R.B.: Leisure activities and risk of vascular cognitive impairment in older adults. J. Geriatr. Psychiatry Neurol. 22(2), 110-118 (2009)

Verhaeghen, P., Cerella, J.: Aging, executive control, and attention: a review of meta-analyses. Neurosci. Biobehav. Rev. 26(7), 849857 (2002)

Verleger, R., Jaśkowski, P., Wascher, E.: Evidence for an integrative role of P3b in linking reaction to perception. Int. J. Psychophysiol. 19, 165-181 (2006)

Voelcker-Rehage, C., Godde, B., Staudinger, U.M.: Physical and motor fitness are both related to cognition in old age. Eur. J. Neurosci. 31(1), 167-176 (2010)

Voelcker-Rehage, C., Godde, B., Staudinger, U.M.: Cardiovascular and coordination training differentially improve cognitive performance and neural processing in older adults. Front. Human Neurosci. 17, 5-26 (2011)

Walford, R.L., Mock, D., MacCallum, T., Laseter, J.L.: Physiologic changes in humans subjected to severe, selective calorie restriction for two years in biosphere. 2: Health, aging, and toxicological perspectives. Toxicol. Sci. 52, 61-65 (1999) (2 Suppl.)

West, R.: An application of prefrontal cortex function theory to cognitive aging. Psychol. Bull. 120(2), 272-292 (1996)

Whitlock, J.R., Heynen, A.J., Shuler, M.G., Bear, M.F.: Learning induces long-term potentiation in the hippocampus. Science 313(5790), 1093-1097 (2006)
Wild-Wall, N., Hohnsbein, J., Falkenstein, M.: Effects of ageing on task preparation as reflected by event-related potentials. Clin. Neurophysiol. 118(3), 558-569 (2007)

Wild-Wall, N., Hohnsbein, J., Falkenstein, M.: Flanker interference in young and old participants as reflected in event-related potentials. Brain Res. 1211, 72-84 (2008)

Wild-Wall, N., Gajewski, P.D., Falkenstein, M.: Kognitive Leistungsfähigkeit älterer Arbeitnehmer. Z. Gerontol. Geriatr 42, 299-304 (2009)

Willis, S.L., Tennstedt, S.L., Marsiske, M., Ball, K., Elias, J., Koepke, K.M., Morris, J.N., Rebok, G.W., Unverzagt, F.W., Stoddard, A.M., Wright, E.: ACTIVE Study Group. Long-term effects of cognitive training on everyday functional outcomes in older adults. JAMA 296(23), 2805-2814 (2006)

Willis, S.L., Schaie, K.W.: Training the elderly on the ability factors of spatial orientation and inductive reasoning. Psychol. Aging 1(3), 239-247 (1986)

Wilson, R.S., Beckett, L.A., Bennett, D.A., Albert, M.S., Evans, D.A.: Change in cognitive function in older persons from a community population: relation to age and Alzheimer disease. Arch. Neurol. 56(10), 1274-1279 (1999)

Witte, A.V., Fobker, M., Gellner, R., Knecht, S., Floel, A.: Caloric restriction improves memory in elderly humans. Proc. Natl. Acad. Sci. USA 106(4), 1255-1260 (2009)

Wu, W., Brickman, A.M., Luchsinger, J., Ferrazzano, P., Pichiule, P., Yoshita, M., Brown, T., DeCarli, C., Barnes, C.A., Mayeux, R., Vannucci, S.J., Small, S.A.: The brain in the age of old: the hippocampal formation is targeted differentially by diseases of late life. Ann. Neurol. 64(6), 698-706 (2008)

Yordanova, J., Kolev, V., Hohnsbein, J., Falkenstein, M.: Sensorimotor slowing with ageing is mediated by a functional dysregulation of motor-generation processes: evidence from high-resolution eventrelated potentials. Brain 127(2), 351-362 (2004)

Patrick D. Gajewski studied biological psychology and defended his doctoral thesis "Encoding Processes during Task Switching" at the Faculty of Mathematics and Natural Science at the University of Düsseldorf. Since 2001 he has been working at the Leibniz Research Center for Working Environment and Human Factors (IfADo) in Dortmund as a research assistant in the project group "Flexible Behavior Control" and since 2007 in the group "Ageing and CNS Dysfunctions" in a project "PFIFF: Program for improving cognitive abilities in older employees". His research interests are psychophysiology of control processes and changes of executive functions across the lifespan.

Michael Falkenstein received diplomas in Electrical Engineering and in Psychology as well as the state exam in medicine. He received the Venia Legendi for Psychology in 1996. Since 1996 he has been working at the Leibniz Research Center for Working Environment and Human Factors (IfADo) in Dortmund, Germany and is head of the project group "Ageing and CNS Dysfunctions" and of the research initiative "Elderly Workers" at IfADo. His main research topics are electrophysiological measures of higher cognitive functions in young and elderly subjects, modulation of age-related cognitive changes by environment and occupation, and interventions to ameliorate age-related cognitive changes. 